\title{
What Effect Does Rehabilitation of Wastewater Pipelines Have on the Share of Infiltration and Inflow Water (I/I-Water)?
}

\author{
Kristin Jenssen Sola ${ }^{1,2, *}$, Jarle Tommy Bjerkholt ${ }^{1,3}$, Oddvar Georg Lindholm ${ }^{1}$ and Harsha Ratnaweera ${ }^{1}$ \\ 1 Faculty of Mathematical Sciences and Technology, Norwegian University of Life Sciences, 1430 Ås, Norway; \\ jarle.t.bjerkholt@usn.no (J.T.B.); oddvar.lindholm@nmbu.no (O.G.L.); harsha.ratnaweera@nmbu.no (H.R.) \\ 2 The Municipality of Asker, 1372 Asker, Norway \\ 3 Faculty of Technology, Natural Sciences and Maritime Sciences, University of South-Eastern Norway, \\ 3603 Kongsberg, Norway \\ * Correspondence: kristin.jenssen.sola@asker.kommune.no; Tel.: +47-41632184
}

Citation: Sola, K.J.; Bjerkholt, J.T.; Lindholm, O.G.; Ratnaweera, H. What Effect Does Rehabilitation of Wastewater Pipelines Have on the Share of Infiltration and Inflow Water (I/I-Water)? Water 2021, 13, 1934. https://doi.org/10.3390/w13141934

Academic Editor: Caetano C. Dorea

Received: 26 May 2021

Accepted: 10 July 2021

Published: 13 July 2021

Publisher's Note: MDPI stays neutral with regard to jurisdictional claims in published maps and institutional affiliations.

Copyright: (C) 2021 by the authors. Licensee MDPI, Basel, Switzerland. This article is an open access article distributed under the terms and conditions of the Creative Commons Attribution (CC BY) license (https:/ / creativecommons.org/licenses/by/ $4.0 /)$.

\begin{abstract}
Infiltration and inflow water (I/I-water) is a big challenge in sewage systems in many countries. I/I-water above an acceptable level indicates that the sewage system is not functioning properly. I/I-water leads to increased pumping costs and increased sewage overflow, leading to increased pollution of the receiving waters. Many rehabilitation projects are driven by the need to reduce the share of I/I-water and common measures are to replace pipes and manholes. The share of I/I-water is predominantly driven by rainfall. This makes it difficult to document the efficiency of mitigating measures. One way to address this issue is to compare data from rehabilitation areas to areas where no measures have been implemented. Three rehabilitation areas in Asker Municipality, Norway, were successfully assessed by applying this approach. Asker has a $100 \%$ separate system. The strategy to reduce I/I-water in Asker Municipality was to rehabilitate sewage mains, either by full replacement or lining the old pipes, and replacement of manholes. The assessment shows that rehabilitation of selected municipal pipes, pipes proven to be in bad condition through closed circuit TV inspection, reduced the share of I/I-water only to a limited extent. Since the rehabilitation done was not a complete replacement of all pipes and manholes, the limited effects are assumed to be caused by the water finding other ways into the system. In separate systems other measures than renovations of pipes should be considered when aiming to reduce I/I-water.
\end{abstract}

Keywords: infiltration and inflow water (I/I-water) measures; measurements; wastewater

\section{Introduction}

Wastewater systems are composed of components such as manholes, pipes, and pumping stations. All these components are affected by multiple factors such as aging and deterioration, and climate change, with an increasing amount of rainfall and urbanization $[1,2]$. Infiltration and inflow water (I/I-water) is common in sewage systems. However, I/I-water represents unwanted water in the sewage system. Combined sewage systems are normally designed to transport a certain volume of stormwater in addition to sewage, as for separate systems all stormwater entering the system is unwanted. The share of I/I-water in a sewage system is an indicator for how well the system is serving its original purpose. I/I-water originates from groundwater, rainfall, rivers, and drinking water leakages [3-7]. I/I-water enters the sewage system thorough leaky pipes and manholes and stormwater pipes incorrectly connected to the system. The sources that contribute the most to the share of I/I-water vary geographically. However, in most places, rainfall strongly influences the share of I/I-water in the wastewater pipeline system $[3,8,9]$. This means that climate change most likely will contribute to larger amounts of I/I-water. This also means that in two otherwise identical localities, the area with higher annual rainfall is likely to have higher annual rates of I/I-water. 
Excessive I/I-water has both social, economic, and environmental impacts. The economic consequences are associated with increased pump operation and less efficient treatment at wastewater treatment plants (WTP). The environmental consequences are linked to overflow discharge, increased outflow of pollutants due to increased flow of water through the WTP, and lower treatment rates at the WTPs [6-10]. The social aspects are linked to the number of basement floodings and potentially reduced access to clean water [8].

A simple method to determine the share of I/I-water in wastewater systems is to measure the flow in the wastewater pipeline system, and compare this measured flow to the number of person equivalents (PE) connected and drinking water use in that same system $[7,11]$. This method is called the water balance method. Another simple and commonly used method is to calculate the level of I/I-water using the dilution method [8,9]. The input to this method is measurements of, for instance, total phosphorus (TOT-P) entering the wastewater treatment plant, the number of connected PEs, and assumptions of TOT-P production per person per day [11,12]. Both methods have drawbacks. The water balance method does not include water that disappears out of the system. The dilution method does not include the inflow of TOT-P into the system. The water balance method depends on measured figures of drinking water consumption; the dilution method depends on figures related to TOT-P production/PE/day. In both methods, there are uncertainties related to equipment/measuring methods.

We may also find more advanced methods aimed at quantifying I/I-water. The use of isotopes is an example of such a method [13]. The use of distributed temperature sensing (DTS) has also proven to be an efficient method when aimed at identifying entry points of inflow water $[6,14]$. However, because both water flow data and data of TOT-P often are easily available to most decision-makers, the water balance method and the dilution method are widely used in Norway.

Renovating sewer pipes, establishing retention basins, and upsizing undersized components (bottlenecks) in the wastewater system are all traditional ways of dealing with unwanted impacts from I/I-water on the wastewater system [8]. Rehabilitating wastewater pipes may result in improving both the condition and the functionality of the pipes. To identify which pipes to renovate, a closed circuit TV inspection (CCTV) can be used [6]. As the amounts of I/I-water are largely influenced by rainfall, water flow measurements carried out before and after measures have been implemented are unlikely to be comparable. Rainfall varies greatly, both in terms of geography and time, and it is challenging to identify two completely identical precipitation events. One workaround for this challenge would be to compare I/I-water levels prior to and after rehabilitation during dry weather events, but such comparisons would not provide an accurate picture of the situation, as the share of I/I-water is likely to be higher during rainfall. Another approach may be to compare water flows before and after measurements in a rehabilitation area, with a control area in which no interventions are made [15]. Using a control area gives a reference point that is independent of any precipitation events that may occur. The control area should be comparable to the rehabilitation area in terms of length of pipes, numbers of manholes, age of pipes/manholes, paved areas, and the number of connected PE. However, most importantly, the areas should be located close to each other.

A number of indicators are used in order to assess the state of the water and wastewater systems. Indicators commonly used are volumes and frequency of overflows, amount of infiltration and inflow water, the number of basement floodings, and the renovation rate $[7,16]$. These indicators are divided into two main categories: indicators aimed at measuring the functionality of the system and indicators aimed at measuring the condition of the system. Infiltration and inflow water (I/I-water) reflects wastewater system malfunctions and may therefore be used as an indicator of the functionality of wastewater systems.

The purpose of the presented study is to calculate the share of I/I-water in separate wastewater systems in selected areas in Asker Municipality in Norway, both before and after implementing measures. The study also aims at assessing whether introduced mea- 
sures within the areas have had an impact on the level of I/I-water. In order to examine the impact of the completed measures to prevent I/I-water, two control areas are included in the study. The main goal of the project is to test out the mentioned method to understand whether it can be useful on a general basis for this type of analysis for I/I-water.

\section{Materials and Methods}

\subsection{Study Area}

Asker Municipality is located southwest of Norway's capital, Oslo. Asker has seasonal variations with cold winters, heavy rain during spring and autumn, and dry summers. Asker's location in Norway is shown in Figure 1.

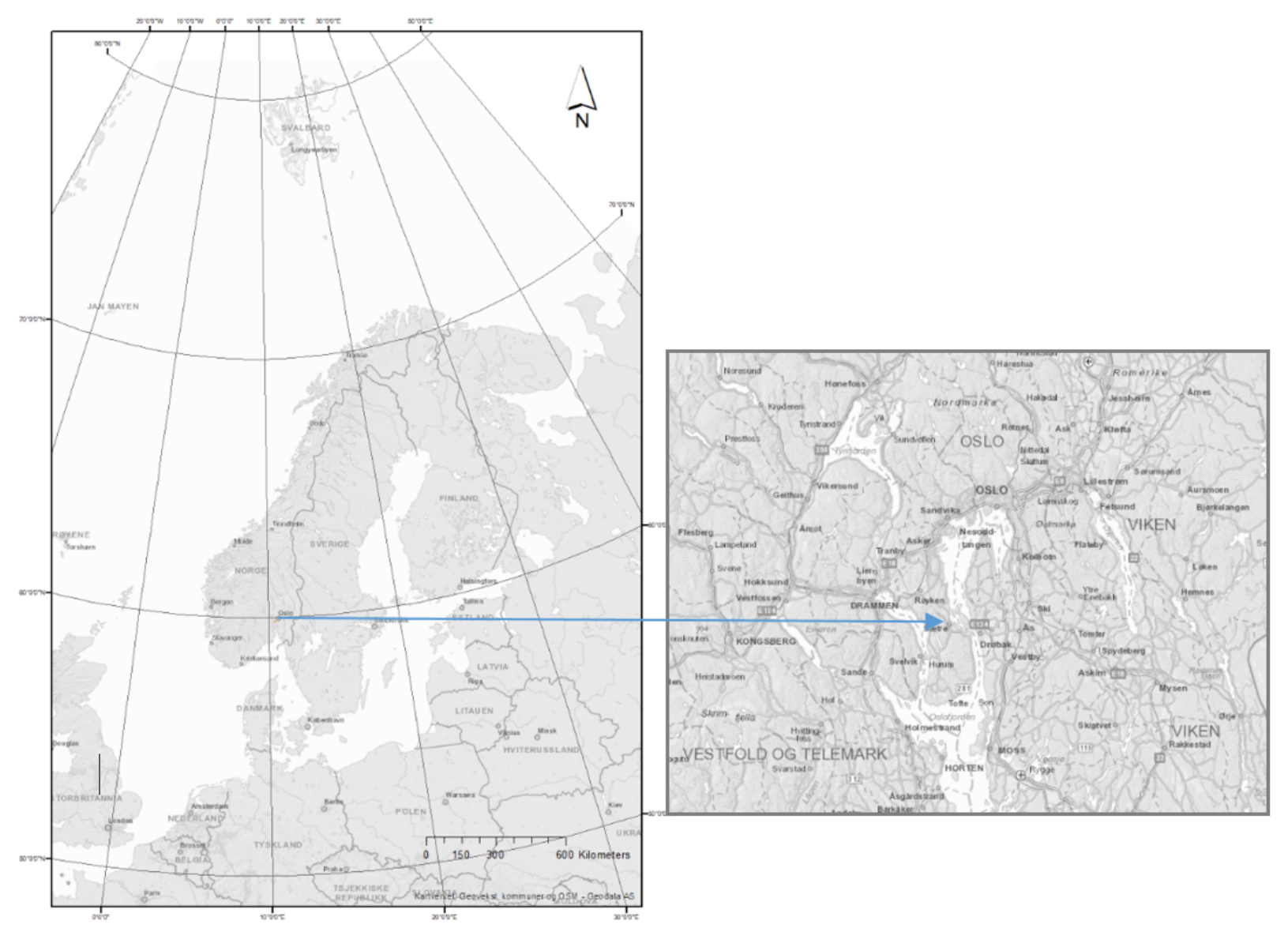

Figure 1. Map of Norway and section of Asker.

Most of the wastewater system in Asker was built in the 1960s and 1970s. The wastewater network consists of concrete pipes and PVC. The renovation rate for the past 5 years has been approximately $1.5 \%$, which is lower than the estimated necessary rate of $2 \%$ [17]. The renovation method is, in most cases, sliplining old concrete pipes. The pipes to be renovated are chosen based on the calculation of I/I-water and CCTV inspection. The entire wastewater system is a separate system. Even so, the sewer network acts more like a combined system. In 2020 the share of I/I-water amounted to about $66 \%$ of the total amount of water delivered to the wastewater treatment plant (WTP). These calculations are based on the water balance method [11].

The strategies for the water and wastewater business in Asker are anchored in the master plan for water and wastewater services in Asker from 2017. In this plan, I/I-water was identified as one of the main challenges [17]. At a tactical level, the utility defines several renovation zones. These zones are defined based on the identified needs of both the wastewater pipes and drinking water pipes. Bad functionality of sewer pipes is weighted 
high when defining these zones. Errors like cracks, staggered joints, and obvious leakages will lead to renovation. Trying to combat the challenges posed by I/I-water, measurements have been implemented in several of the renovation zones. Since the system is a $100 \%$ separate system, the main measure has been the rehabilitation of sewer pipes, as well as troubleshooting for faulty connected stormwater. Three of these rehabilitation zones are assessed in this study: Dæli, Vakås, and Vestre vei. The areas were selected based on previous assessments of I/I-water that indicated that the areas contribute to a large extent to the high level of I/I-water in the utility. The level of I/I-water prior to implementing the measures varied between 40 and $90 \%$, depending on the weather situation. The rehabilitation areas and the sewer system in Asker are shown in Figure 1. The locations of the two rain gauges are marked in Figure 2, along with the two areas used as control areas.

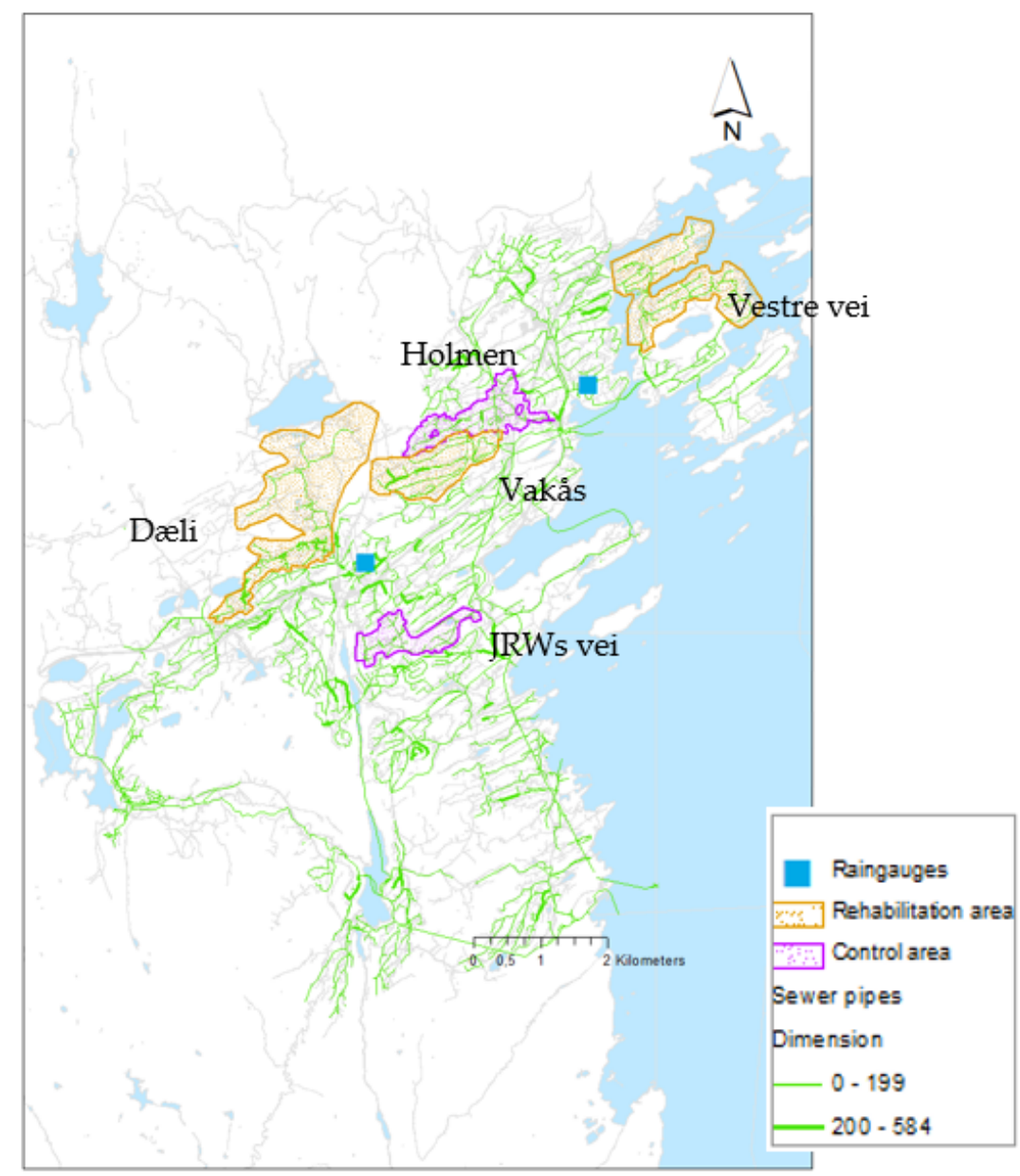

Figure 2. Overview map of the investigated areas as well as rain gauge locations.

Prior to the rehabilitation, in 2015, 2016, and 2017, water flow meters were installed in the rehabilitation areas and the control areas. The first area in which measures were implemented was Dæli. Vakås is an area where-as of 1 January 2021—rehabilitation is ongoing, but many measures have already been implemented. Measures were implemented in the Vestre vei area in 2019. J. R. Wilhelmsens vei (JRWs vei) and Holmen were included as control areas, as no measures were implemented in those areas during the time periods covered in this study. The rain gauge in the north is called "Mellom Nes" and is used when looking at Vestre vei/Holmen. The rain gauge between Vakås/Dæli and JRWs vei is called "the fire station." All assessed areas are residential areas with no industrial activity. The calculations do not account for commuting.

There are no overflow points in JRWs vei, Dæli, or Vakås, but there are overflow points associated with sewage pumping stations in Holmen and Vestre vei. Both overflow points 
and pumping stations are located downstream of the measuring points of discharge and did not influence the calculations.

There is no tradition of measuring the groundwater table in Asker, so there are no data on how the wastewater discharges are affected by groundwater.

\subsection{Method to Assess the Effect of Rehabilitation}

To investigate the impact of the renovations, water flow levels and I/I-water volumes were examined and compared under different weather conditions, including both dry and wet weather events. Rehabilitated areas were examined and compared to the control areas before and after the rehabilitation.

Figure 3 illustrates the method utilized to investigate the impact of the renovations.

\begin{tabular}{|c|c|c|}
\hline $\begin{array}{l}\text { Control area } \\
\text { Amount of I/I-water during dry weather } \\
\text { Amount of I/I-water during rainfall } \\
\text { The shape of the curves } \\
\text { Discharge through weirs }\end{array}$ & $\begin{array}{l}\text { Rehabilitation area } \\
\text { Amount of I/I-water during dry weather } \\
\text { Amount of I/I-water during rainfall } \\
\text { The shape of the curves } \\
\text { Discharge through weirs }\end{array}$ & $\begin{array}{l}\text { Before } \\
\text { measures }\end{array}$ \\
\hline \multicolumn{2}{|c|}{ 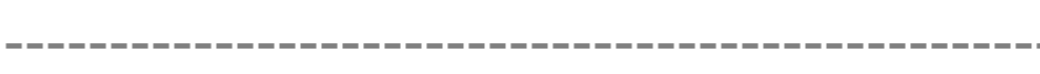 } & \\
\hline $\begin{array}{l}\text { Control area } \\
\text { Amount of I/I-water during dry weather } \\
\text { Amount of I/I-water during rainfall } \\
\text { The shape of the curves } \\
\text { Discharge through weirs }\end{array}$ & $\begin{array}{l}\text { Rehabilitation area } \\
\text { Amount of I/I-water during dry weather } \\
\text { Amount of I/I-water during rainfall } \\
\text { The shape of the curves } \\
\text { Discharge through weirs }\end{array}$ & After \\
\hline
\end{tabular}

Figure 3. Schematic drawing of the method used to investigate the impact of measures in the rehabilitation areas.

In order to carry out the evaluation of the effect from the rehabilitation, it was essential to obtain reliable flow data from all areas.

\subsection{Measuring Equipment}

In the analyses conducted for this study, data were retrieved from two rain gauges located in Asker. These gauges have been in operation since March 2015 (Mellom Nes) and March 2016 (Asker fire station) [18]. The rain gauges also measure snowfall during the winter season.

Table 1 outlines the characteristics of the water flow measuring devices used [19].

Table 1. Characteristics of the measuring devices used in the different zones.

\begin{tabular}{llll}
\hline Area & \multicolumn{1}{c}{$\begin{array}{c}\text { Dimension of Pipes in Which } \\
\text { the Gauge Was Installed }\end{array}$} & Type of Measuring Device & $\begin{array}{c}\text { Measurement Uncertainty } \\
\text { (during Good Conditions) }\end{array}$ \\
\hline Dæli & $315 \mathrm{~mm}$ & PCM4 with POA sensor & $0-10 \%$ \\
\hline Vakås & $250 \mathrm{~mm}$ & $\begin{array}{l}\text { PCM4 with CSM-P sensor and } \\
\text { air ultrasound }\end{array}$ & $5-10 \%$ \\
\hline Holmen & $400 \mathrm{~mm}$ & PCM4 with POA sensor & $0-10 \%$ \\
\hline JRWs vei & $290 \mathrm{~mm}$ & PCM-F with KDA sensor & $0-15 \%$ \\
\hline Vestre vei & $230 \mathrm{~mm}$ & PCM4 with POA sensor & $0-10 \%$ \\
\hline
\end{tabular}

The PCM4 and PCMF sensors both use the same principle to determine the flow Q. The method is shown in Formula (1).

$$
\mathrm{Q}=\mathrm{v} \text { (average }) \times \mathrm{A}
$$


where:

$\mathrm{Q}=$ flow;

$\mathrm{v}=$ flow velocity;

$A=$ flow cross-section.

The flow cross-section A is determined by continuously measuring the filling level, taking the channel shape as well as the channel dimensions into account. The filling level in the pipe is measured with two independent level sensors, a pressure sensor at the bottom of the pipe and an ultrasonic level sensor at the top of the pipe. The flow velocity is determined with the PCM4 equipment based on an ultrasonic reflection principle, whereas the PCMF equipment has a velocity sensor based on the classic Doppler method [20-22].

Several conditions need to be met to achieve reliable flow data. The pipe in which the meter is installed should be straight without bends and have a constant diameter. The water flow should be as steady as possible, meaning that the pipe should maintain a steady and limited incline and not intersect with feed pipes. Experiences from Asker Municipality in Norway suggest that the ideal water flow rate for measurements is around $21 /$ s. Normally, flows of 21 /s correspond to areas servicing $1000 \mathrm{PE}$, which is a relatively large area. The limited sensitivity of current measurement technology makes it difficult to get good data from smaller drainage areas. Generally, pipeline renovations are conducted on small segments of the pipeline system, usually where the need is considered the greatest based on CCTV inspections. Since such a large area is required to get reliable water flow measurements, the share of rehabilitated pipes will be relatively small compared to the total pipe length within the area observed.

The flow meters used are intended to log data continuously. However, there are often operational outages that disrupt the data series. Since timeouts are relatively common in the time series, it can be difficult to find periods with reliable measurement data for several areas at the same time. This poses a challenge to comparing measurements from different areas. Conducting extended measurement periods is, therefore, crucial to obtain reliable data that can be used in comparative studies. The series selected for this study meets the abovementioned criteria. In the data used for this study, there are frequent timeouts. The use of water flow measurements to evaluate I/I-water requires close monitoring of the measuring devices.

\subsection{Calculation Method}

In the calculations performed in the presented study, measured water flow was used to calculate the share of I/I-water by using the water balance method. Water consumption is not measured in all households in Asker. The calculations utilize a stipulated daily water consumption of $140 \mathrm{l} / \mathrm{PE}$ based on experience from houses where water use is measured [11]. Since no overflow points were identified upstream of the measuring points, the calculations did not take into account any water losses. The water balance method is shown in Formula (2) [11,12].

$$
(\% \text { share of } \mathrm{I} / \mathrm{I} \text {-water })=\left(\mathrm{Q}_{\text {tot }}-\mathrm{PE} \times \mathrm{Q}_{\mathrm{ap}}\right) /\left(\mathrm{Q}_{\mathrm{tot}}\right) \times 100
$$

where:

$\mathrm{I} / \mathrm{I}=\mathrm{I} / \mathrm{I}-$ water in the wastewater system (\%);

$\mathrm{Q}_{\text {tot }}=$ total amount of water transported to the measuring point (l/day);

$\mathrm{PE}=$ the number of persons situated within the catchment area;

$\mathrm{Q}_{\mathrm{ap}}=$ the amount of wastewater each person produces a day (l/PE/day).

\subsection{Description of the Selected Catchments}

Characteristics of the sewer pipes and drinking water pipes in the renovation zones (Dæli, Vakås, and Vestre vei) are shown in Table 2. The table also includes some characteristics of the control zones (JRWs vei and Holmen). 
Table 2. Characteristics of the wastewater systems in Dæli, Vakås, and Vestre vei.

\begin{tabular}{|c|c|c|c|c|c|c|}
\hline \multirow{2}{*}{ Area } & \multirow{2}{*}{$\begin{array}{l}\text { Total Length } \\
\text { of Pipes (m) }\end{array}$} & \multirow{2}{*}{$\begin{array}{l}\text { Number } \\
\text { of PE }\end{array}$} & \multirow{2}{*}{$\begin{array}{l}\text { Rehab. } \\
\text { Sewer Pipes } \\
\%\end{array}$} & \multirow{2}{*}{$\begin{array}{l}\begin{array}{l}\text { Rehab. } \\
\text { Manholes }\end{array} \\
\%\end{array}$} & \multirow{2}{*}{$\begin{array}{l}\text { Average Age of } \\
\text { Selected Pipes }\end{array}$} & \multirow[t]{2}{*}{ Average Age of Remaining Pipes } \\
\hline & & & & & & \\
\hline Dæli & 12,181 & 3136 & 13 & 12 & About 50 & $\begin{array}{l}24 \% \text { of pipes less than } 20 \text { years old } \\
\text { Remaining pipes: about } 40 \text { years old }\end{array}$ \\
\hline Vakås & 9480 & 1886 & 11 & 13 & About 60 & $\begin{array}{l}34 \% \text { of pipes less than } 20 \text { years old } \\
\text { Remaining pipes: about } 40 \text { years old }\end{array}$ \\
\hline JRWs vei & 6520 & 1026 & Control area & & & \\
\hline Vestre vei & 15,138 & 3087 & 7 & 10 & $\begin{array}{l}\text { Unknown-not } \\
\text { registered }\end{array}$ & $\begin{array}{l}31 \% \text { of pipes less than } 20 \text { years old } \\
\text { Remaining pipes: about } 40 \text { old }\end{array}$ \\
\hline Holmen & 6380 & 1538 & Control area & & & \\
\hline
\end{tabular}

By including the proposed measures, the remaining pipes were assessed to be in good condition in all zones except Vakås. Some additional pipes were selected for renovation in this zone after the extraction of data was finished. The CCTV inspection and site inspection did not reveal additional pipes that should be renovated either in Dæli or in Vestre vei.

The control areas are smaller than the areas they were compared to in terms of the number of inhabitants and the total length of the pipes. This was not ideal, but the selection of perfect measuring points was limited.

The municipality has a strategy to demand rehabilitation of all private sewer pipes connected to the municipal sewer pipes that are being rehabilitated. This is a time-consuming process. In the assessed rehabilitation areas, no private pipes had been rehabilitated before the data used in the study were extracted.

For all areas, primarily old concrete pipelines/manholes had been rehabilitated. Only pipes identified in bad condition through CCTV inspection were selected to be renovated. In Norway, all water and sewage pipes are installed below the maximum frost depth. For Asker Municipality, the minimum depth of installation is $1.7 \mathrm{~m} \mathrm{[23].} \mathrm{The} \mathrm{main} \mathrm{soil} \mathrm{type} \mathrm{in}$ Asker is marine deposited clay.

In addition to being residential areas with only simple road structures, the following characteristics for each of the rehabilitation areas were identified:

Vakås:

- Parts of the sewer system are situated near a small stream.

- Several wrongly connected stormwater pipes where discovered, but none of these were corrected by the time of data collection.

- The work mainly required full excavations and replacement of the concrete pipes with new PVC pipes.

- The manholes selected for rehabilitating were fully replaced.

All the wastewater pipes in Vakås, the pipes selected for renovation, and the rivers in the area are shown in Figure 4.

- The rehabilitation of the pipes was initially prompted by surface water that had been erroneously connected to the wastewater pipeline system. This was fixed. During the process, pipes in bad condition were discovered. These pipes were selected for renovation.

- The work mainly entailed sliplining.

- Limited work was performed on manholes.

Vestre vei:

- Frequent overflow runoff necessitated the redevelopment of wastewater pipelines in the zone. The overflow point was situated downstream of the renovation zone;

- The work mainly entailed sliplining.

- Limited work was performed on manholes, with some manholes being fully encased. 


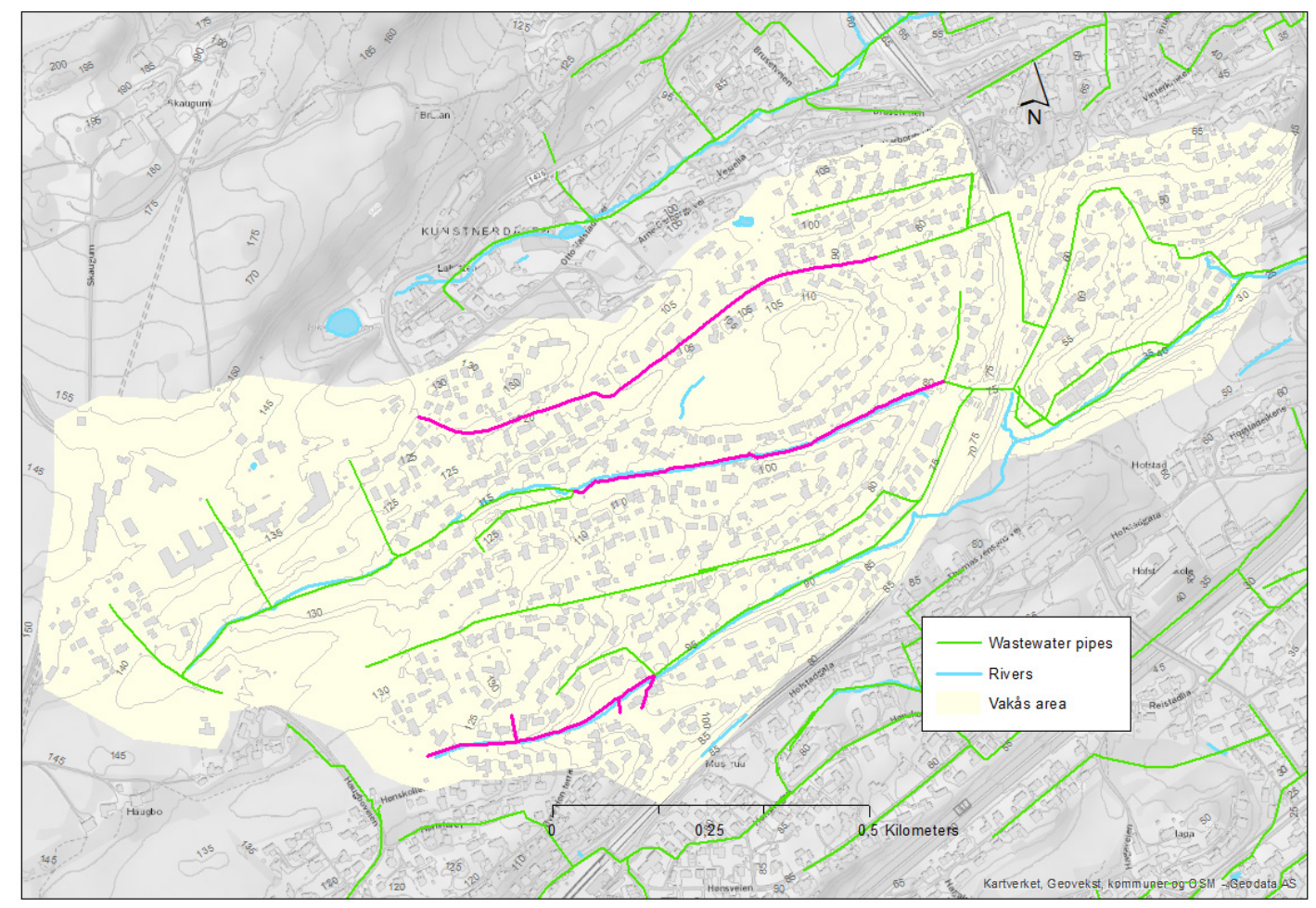

Figure 4. A map of the Vakås area. Pipes selected for rehabilitation are marked in the pink color.

\section{Results and Discussion}

All the main characteristics (urbanization, soil type, and installation depth of pipes) of the selected areas, apart from size, are similar. Unlike the other areas, the groundwater level in the Vakås area is affected by the river. This makes the sewer system in Vakås more susceptible to infiltration of groundwater than in the other areas. Groundwater could infiltrate both pipes and manholes.

The amounts of I/I-water in the rehabilitation areas in the following were compared to the levels in the control zones. If the level sank equally in the control area and the rehabilitation area, it is likely that changes in precipitation caused the reduction and not the renovation of the pipes and manholes. The results are based on the following prerequisite: The assessed rain events occur after a minimum of three days of dry weather. This comparison takes into account neither rainfall conditions before the event in question nor the temperature in the compared periods.

Some of the assessed data sets were extracted during wintertime. During dry weather this did not influence the results. During periods with precipitation the results may have been influenced if the precipitation fell as snow. This problem is discussed in more detail in this section where appropriate.

\subsection{Dry Weather}

\subsubsection{Dæli and Vakås}

Figure 5 shows dry weather periods prior to the implementation of the measures. The figure shows the percentage of I/I-water in the total measured water flow. Even though the entire wastewater system is a separate system, we found a large portion of I/I-water.

For Vakås, the share of I/I-water varied between $84 \%$ and $91 \%$. In JRWs vei, the share of I/I-water varied between approximately $69 \%$ and $79 \%$, whereas the share of I/I-water in Dæli ranged between approximately 59\% and 76\%. In Vakås, the wastewater pipelines traverse a river at several points, which is a likely contributor to the high groundwater table and the high shares of I/I-water. 


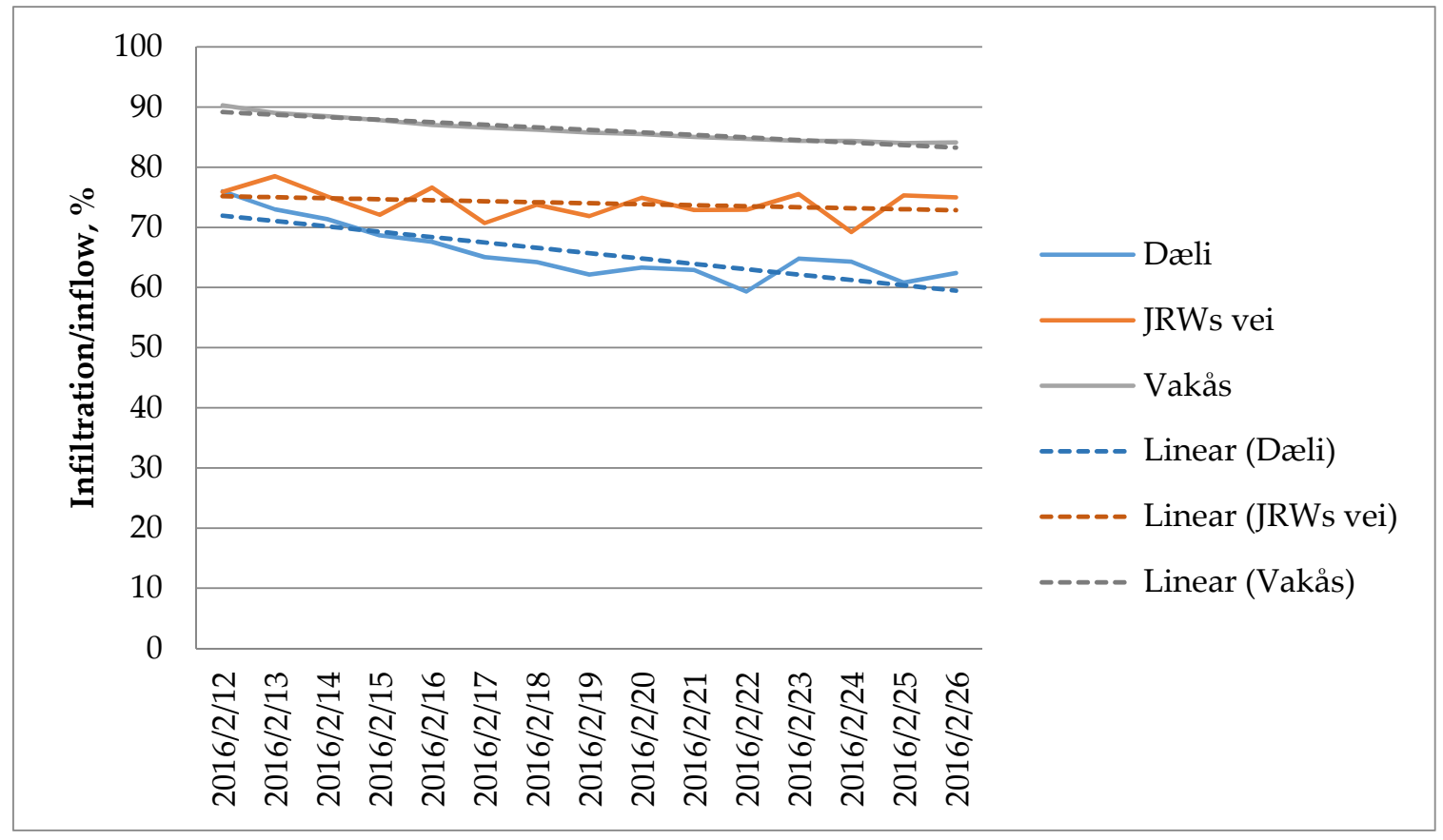

Figure 5. Calculated share of I/I-water in a dry weather period, before the implementation of the measures.

Figure 6 shows dry weather periods after the implementation of the measures.

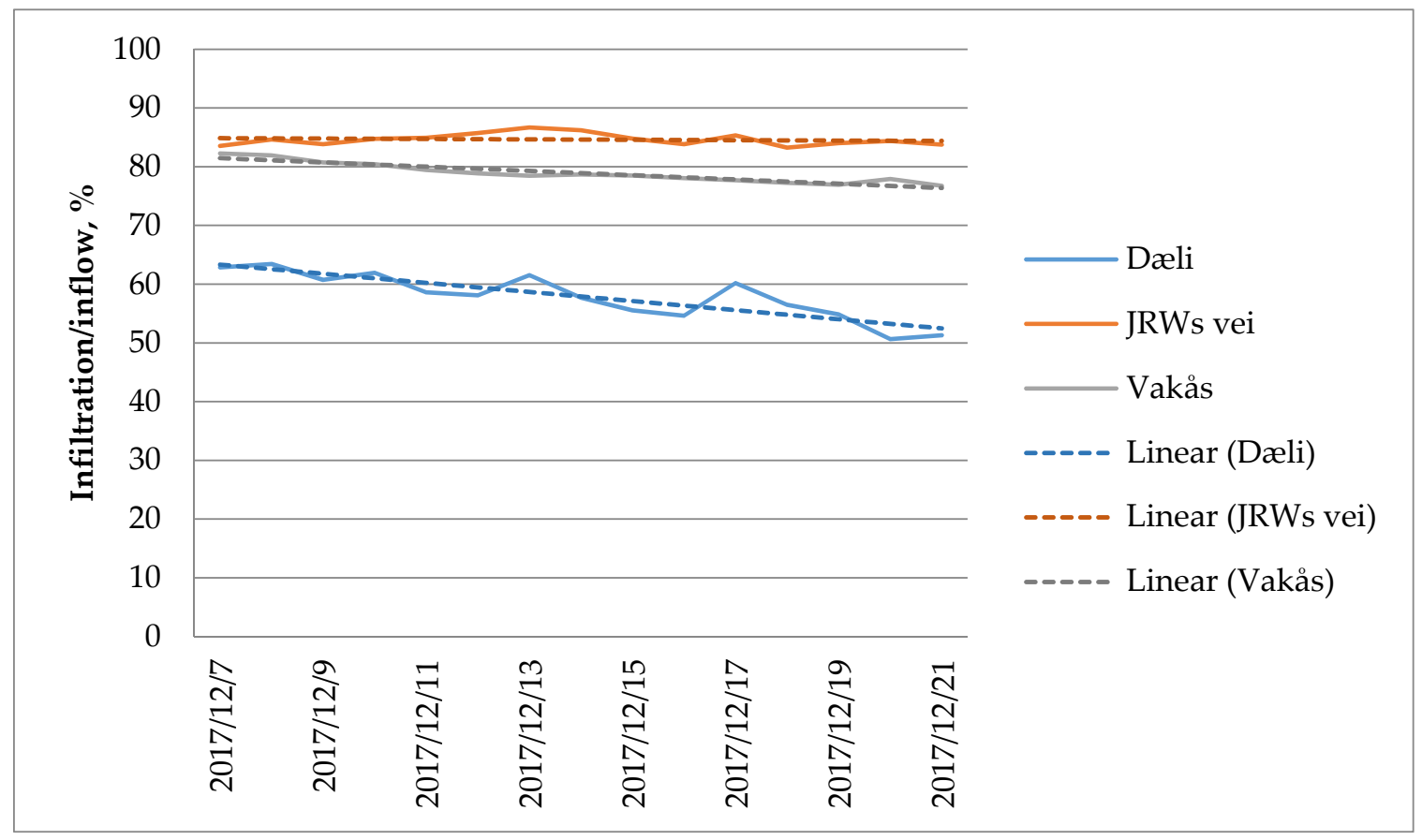

Figure 6. Calculated share of I/I-water during a dry weather period, after the implementation of the measures.

In this period, JRWs vei was the area with the highest share of I/I-water, between $82 \%$ and $87 \%$, which is an increase from the assessed period in 2016. In the Vakås area, the share varied between $77 \%$ and $82 \%$, whereas the share in Dæli varied between an estimated $51 \%$ and $63 \%$. Despite increased shares of I/I-water in the control area when comparing shares of I/I-water before and after the implementation of the measures, we registered a decrease 
in the share of I/I-water in Vakås. This may indicate that the implemented measures had an impact on I/I-water during dry weather periods in this renovation area.

Four different dry weather periods were extracted and analyzed closely:

1. $\quad 12.02 .2016-26.02 .2016$ to $04.05 .2018-13.05 .2018$

2. $\quad 12.02 .2016-26.02 .2016$ to $16.05 .2018-27.05 .2018$

3. $\quad 31.08 .2016-10.09 .2016$ to $04.05 .2018-13.05 .2018$

4. $\quad 31.08 .2016-10.09 .2016$ to 16.05.2018-27.05.2018

The reduction in I/I-water for the areas of Vakås and Dæli is summed up as follows:

Vakås: dry weather $=9-22 \%$

Dæli: dry weather $=0$

Comparisons between the control areas and rehabilitation areas in dry weather suggest that the I/I-water quantities declined only in the Vakås area.

\subsubsection{Vestre Vei}

Figure 7 shows a dry weather period in the summer of 2018. No rainfall was registered during the entire period, meaning that the peak shown for 4666-Holmen must have been due to factors other than rain. Most likely the meter was out of order this day. Another option is that the meter was temporarily covered with particles or sludge. Approximately $30 \mathrm{~mm}$ of rainfall occurred during three days before the assessed dry weather period.

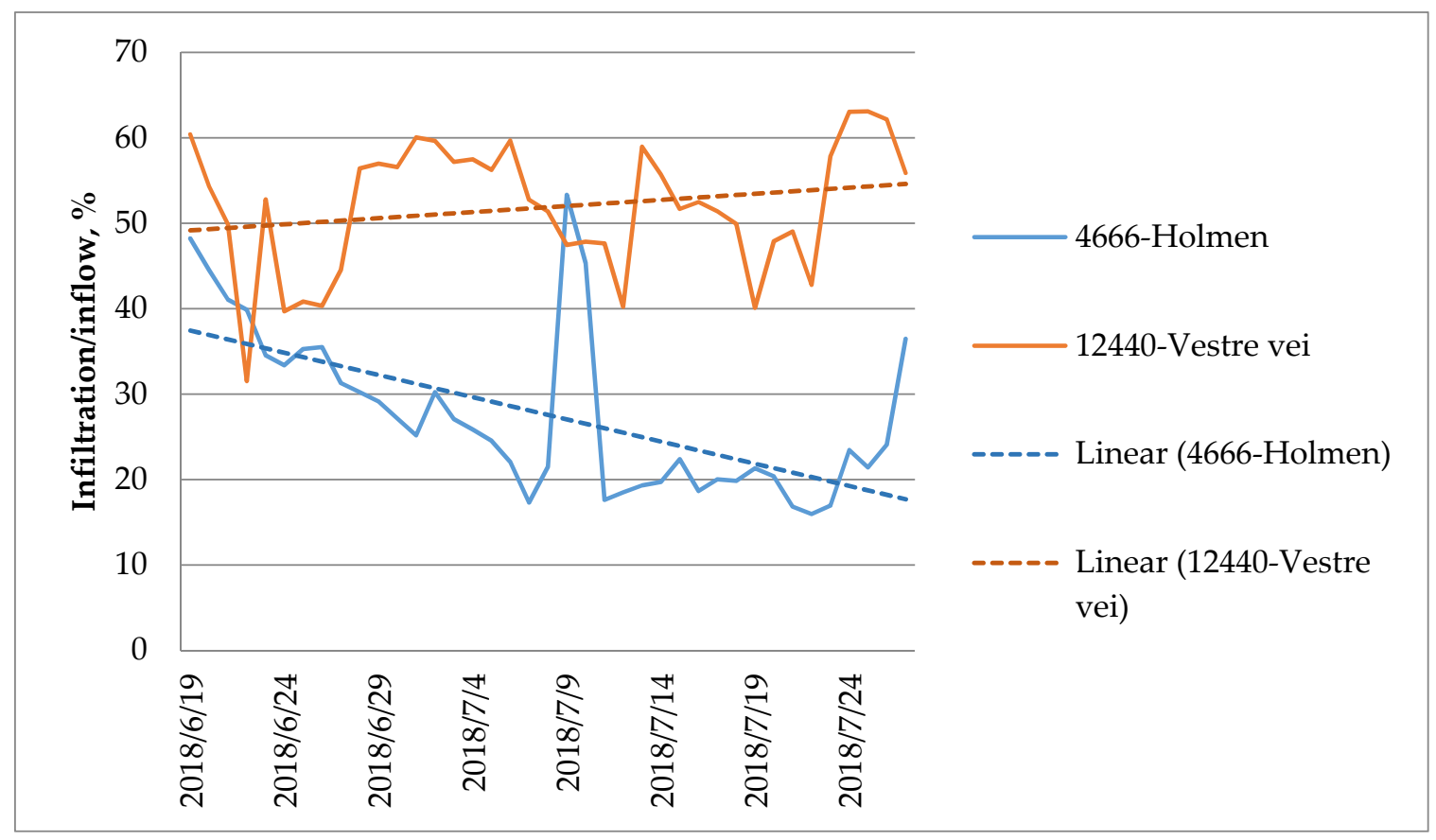

Figure 7. Calculated share of I/I-water in a dry weather period, before the implementation of the measures.

Figure 8 shows the estimated share of I/I-water in a dry weather period after the implementation of the measures in the Vestre vei area. The period prior to the examined dry weather period was relatively wet, with approximately $74 \mathrm{~mm}$ of rainfall over 11 days, which is the reason for the high share of I/I-water at the start of the period. 


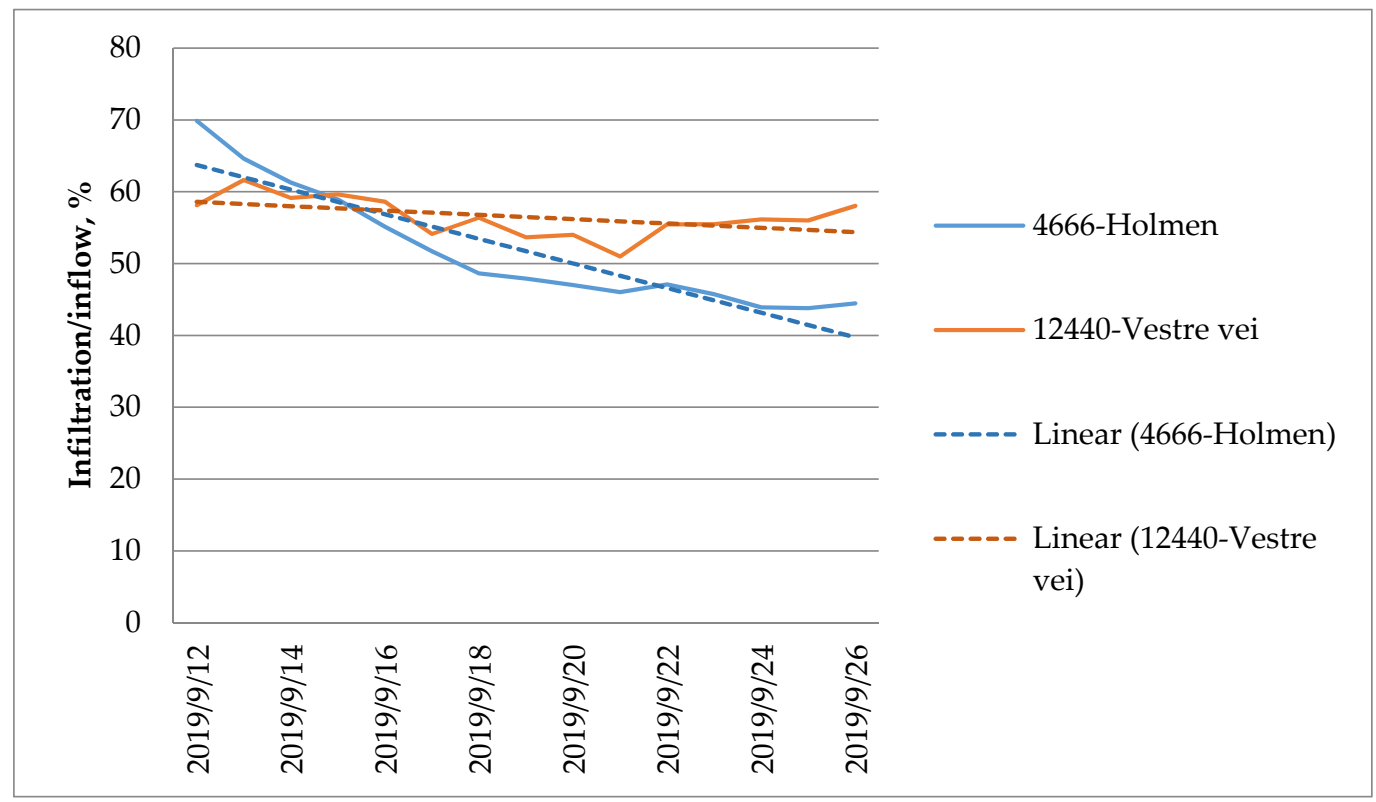

Figure 8. Calculated share of I/I-water in a dry period, after the implementation of the measures.

In the period after the measures were implemented, the lowest estimated I/I-water level in Vestre vei was approximately $50 \%$. In Holmen, the lowest level was approximately $44 \%$. The share of I/I-water in the Vestre vei zone was generally higher than in Holmen. The share of I/I-water for the Holmen zone was thus higher during this period than during the period prior to the measures being completed in Vestre vei. The share of I/I-water in Vestre vei remained rather stable before and after the implementation of the measures.

Three different dry weather periods were extracted an analyzed closely:

1. $\quad 08.12 .2017-25.12 .2017$ to 06.08.2019-09.08.2019

2. $\quad 29.05 .2018-09.06 .2018$ to $06.08 .2019-09.08 .2019$

3. 19.06.2018-08.07.2018 to 15.09.2019-19.09.2019

The reduction in I/I-water during dry weather for the areas of Vestre vei is likely to have been 0 .

\subsection{During Rainfall}

\subsubsection{Dæli and Vakås}

Figure 9 shows rainfall periods prior to the implementation of the measures. The figure shows the percentage of I/I-water in the total measured water flow.

The measured water flow in Dæli shows that the area was heavily affected by rainfall, as the proportion of I/I-water peaked during precipitation events, whereas JRWs vei and Vakås had a consistently high proportion of I/I-water. Vakås and JRWs vei are presumably affected by I/I-water to such a degree that the levels remained generally high. In Dæli, the variations in I/I-water were greater than in the other two areas. The share of I/I-water declined to approximately $50 \%$ in Dæli towards the end of the period. In other words, Dæli is quickly influenced by rainfall and dry weather alike, and the primary sources of I/I-water are presumably directly linked to surface water, and to a lesser extent to infiltration. JRWs vei and Vakås are constantly influenced by groundwater and infiltration is likely to be constantly at a high level.

Figure 10 shows the proportion of I/I-water in all three zones during rainfall after the implementation of the measures. 


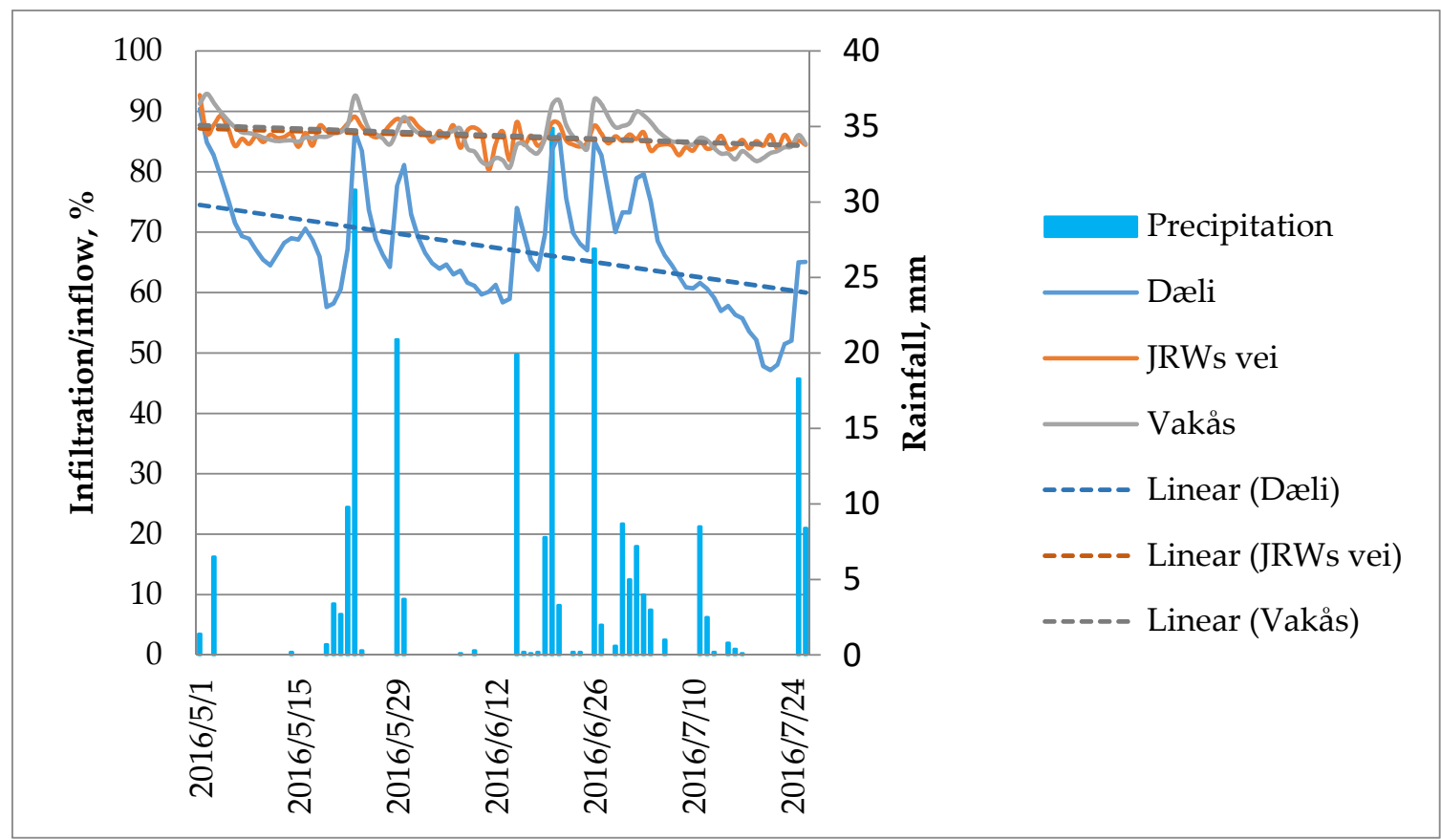

Figure 9. Calculated share of I/I-water in a wet weather period, before the implementation of the measures.

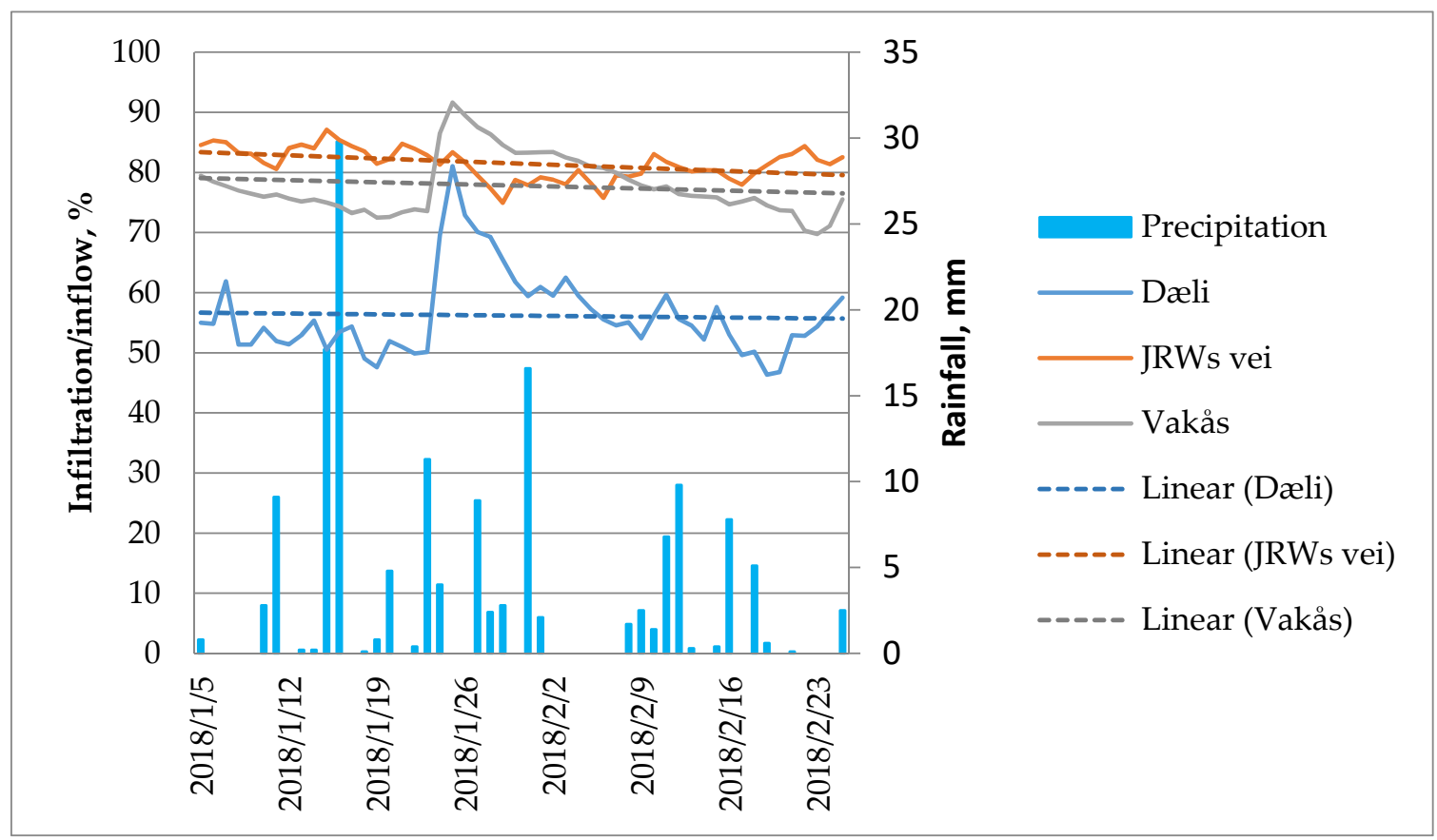

Figure 10. Calculated share of I/I-water in all surveyed points during rainfall, after the implementation of the measures.

Figure 9 shows that the I/I-water share in JRWs vei remained quite stable at approximately $80 \%$, regardless of rainfall. For Vakås, the share varied roughly between $70 \%$ and $91 \%$. The share of I/I-water in the Vakås area was generally lower than the corresponding share in JRWs vei. For Dæli, the share of I/I-water lay between $47 \%$ and $83 \%$. In Figure 8 we saw that the level of I/I-water was approximately the same for the Vakås area and the JRWs vei area. However, in Figure 9, we see that for most of the time JRWs vei was the area with the highest share of I/I-water.

Only two periods with reliable and comparable data were found: 


\section{1. $\quad 18.05 .2016-01.06 .2016$ to $04.05 .2018-13.05 .2018$}

2. $18.08 .2016-02.09 .2016$ to $07.02 .2018-25.02 .2018$

From these two periods it seems that there was a minor reduction in I/I-water in both areas:

Vakås: rainfall $=3-8 \%$

Dæli: rainfall $=7-9 \%$

In the time period from 05.01.2018 to 23.02.2018, as shown in Figure 10, the air temperature changed from below to above zero on 23.01. This change in temperature explains the delay in I/I-water in the system, as the precipitation stored as snow on the ground in the beginning of the period melted in the second part of the period. The maximum measured on 25.01 was caused by melted snow entering the sewer system.

The temperatures in the time period from 07.02.2018 to 25.02.2018, which was one of two periods selected for comparison to the time period from 18.8.2016 to 02.09.2016, fluctuated below and above zero. During this period, the snow melted and entered the sewer system on days with temperatures above zero. However, the temperature and snow cover situation were the same in the control area and the rehabilitation area and the results and trends are therefore comparable. In the selected period the reduction in the share of I/I-water was 5\% in the control area. In the rehabilitated areas of Vakås and Dæli, the reductions were $13 \%$ and $14 \%$, respectively, for the same period.

\subsubsection{Vestre Vei}

Figure 11 shows different rainfall periods before the implemented measures.

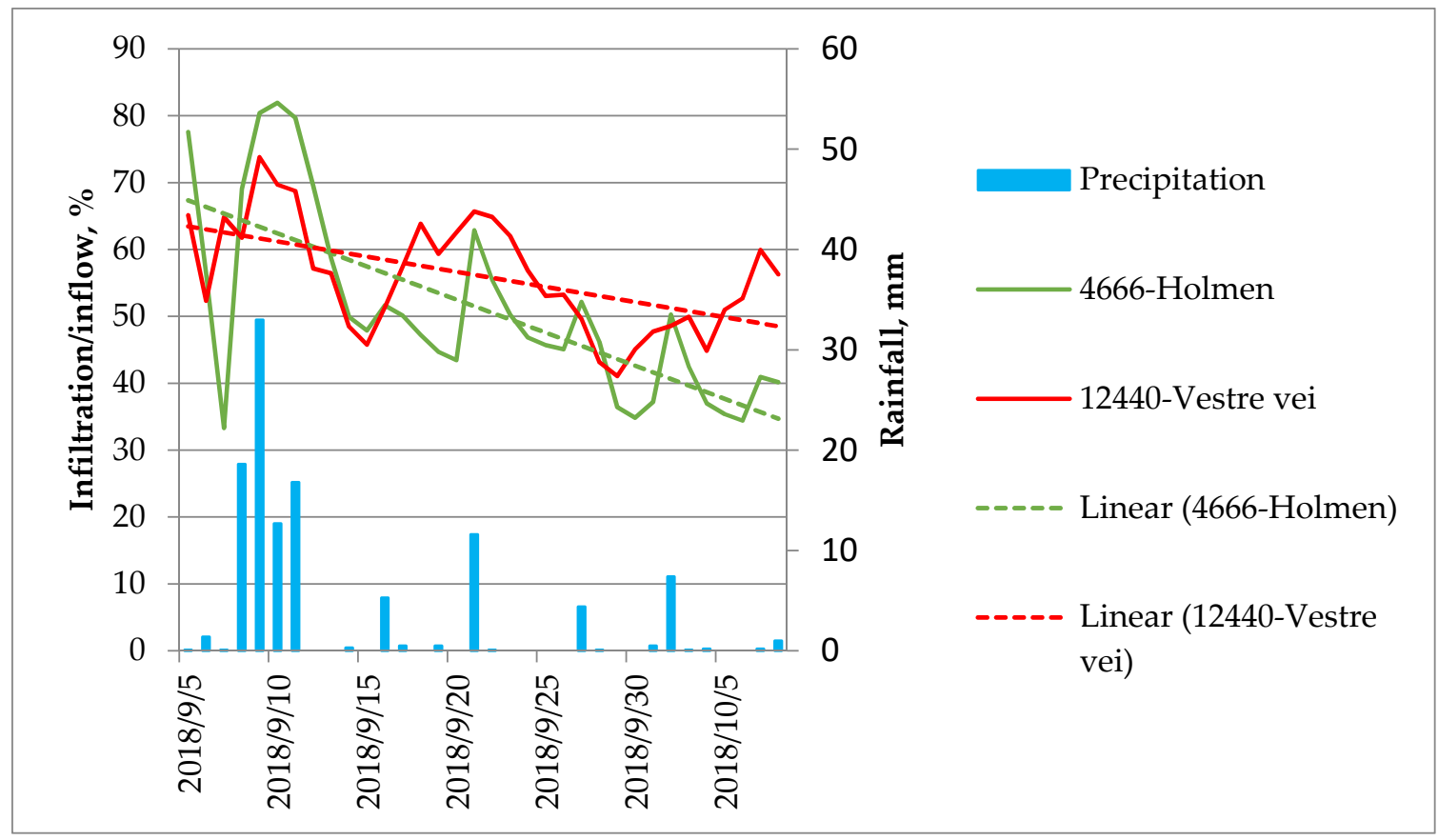

Figure 11. Calculated share of I/I-water in Holmen and Vestre vei in a wet weather period, before the implementation of the measures.

There was no clear pattern during rainfall periods with regards to which site had the highest shares of I/I-water. Both areas were clearly influenced by rainfall. In Figure 10, we can see that the two areas were roughly similarly impacted by rainfall. Holmen had the highest volumes of I/I-water in the first part of the period, whereas Vestre vei had the highest volumes in the latter part of the period. The highest rainfall quantities came in the first part of the period. 
By looking at rainfall in conjunction with the estimated share of I/I-water for all periods, the volumes of I/I-water were greatest in the Holmen zone during high precipitation periods. Holmen was impacted more slowly by rainfall than Vestre vei. Despite that, dry weather readings showed that the share of regular infiltration was greatest in Vestre vei.

Figure 12 shows the share of I/I-water in Holmen and Vestre vei in different rainfall periods after the implemented measures.

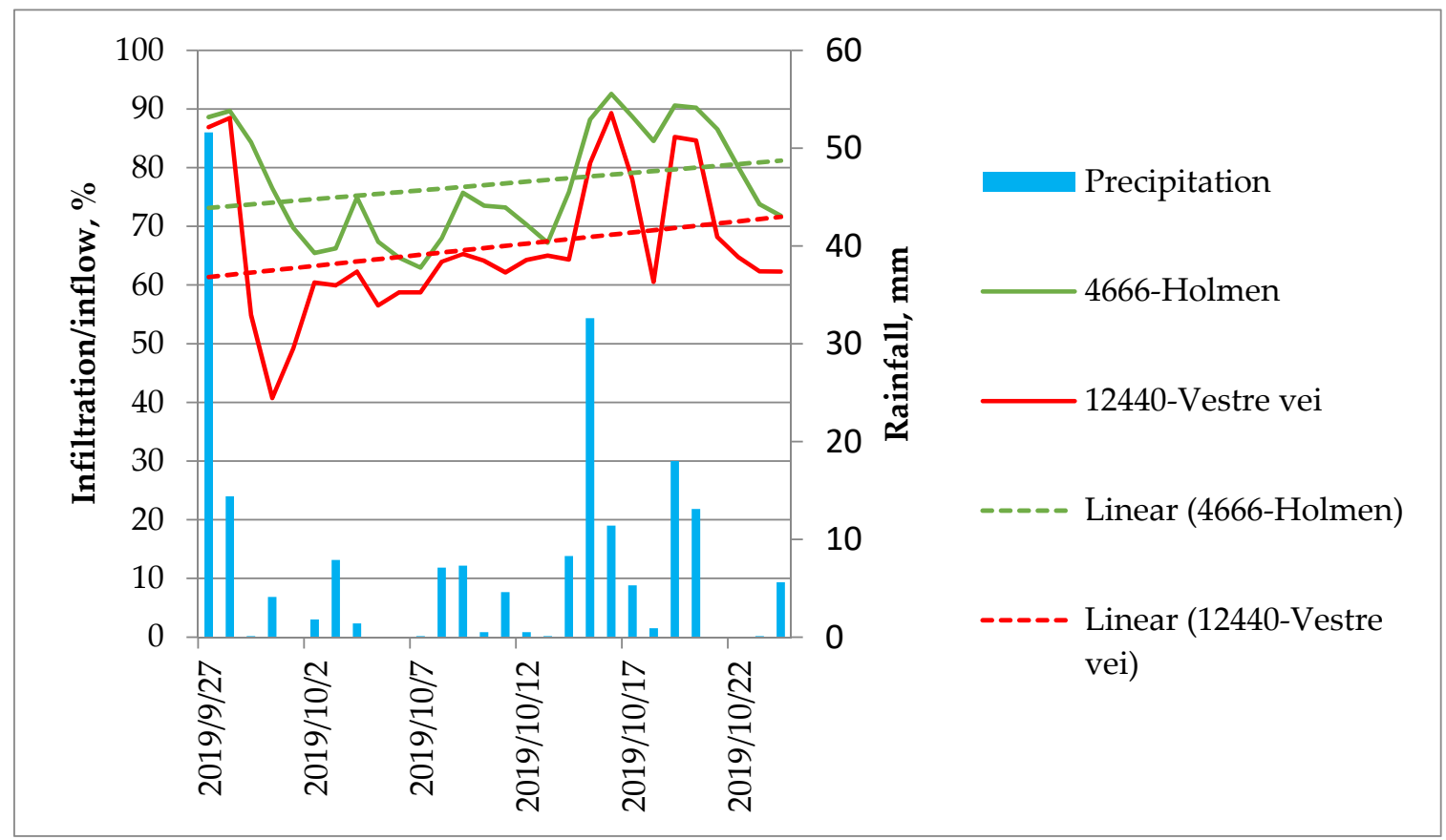

Figure 12. Calculated share of I/I-water during rainfall periods, after the implementation of the measures.

During all rainfall events, we can see that the share of I/I-water was larger in Holmen than in Vestre vei. In Holmen, the share of I/I-water varied between $63 \%$ and $93 \%$. In Vestre vei, the share varied between $40 \%$ and $89 \%$.

Three different periods were extracted an analyzed closely:

1. $\quad 05.11 .2017-10.11 .2017$ to $28.08 .2019-29.08 .2019$

2. 28.07.2018-12.08.2018 to $10.08 .2019-12.08 .2019$

3. $\quad 05.09 .2018-11.09 .2018$ to $27.09 .2019-04.10 .2019$

The reduction of I/I-water for the areas of Vestre vei was likely to be between 11 and $43 \%$.

\section{Conclusions}

The only area where there was a clear reduction of I/I-water in dry weather was Vakås. This was also the only area where the renovation method was a full replacement of selected pipes and selected manholes. Since the Vakås area was under the influence of a river, and therefore also groundwater, it is reasonable to assume that this was the source being reduced during dry weather.

The main conclusion of this study is that rehabilitating only small proportions of pipelines and manholes leads to a small but not proportional reduction in I/I-water. The average age of the wastewater pipes in all three renovation zones is relatively young. However, even after completing the renovation of all pipes assumed to be in bad condition, the level of I/I-water was high. Rehabilitating pipelines with the sole purpose of reducing I/I-water cannot be recommended. In the investigated areas, the rehabilitation of sewer pipes showed only limited results. It is likely to be that by leaving some pipes, even if they are not proven to be in bad condition, I/I-water will find its way into some of them. Water may be transported along the trench to other weak points, entering the system at these 
points instead. Pipes not proven to be in bad condition with CCTV inspection may, after all, not be completely sealed. Private pipes and connection points between municipal pipes and private pipes are also examples of such weak points.

Due to the results in this study, it is clear that indicators aiming at documenting the condition and functionality of the sewer system should be chosen carefully. It may seem that the indicator renovation rate may be misguiding when used to assess the functionality of the pipes. Even when investing large sums of money in renovating pipes, this may not improve the total functionality of the system.

The scope of the presented study was to investigate the effect rehabilitation of municipal pipes has on I/I-water. It is recommended to perform a new study when the rehabilitation of private pipes is completed. It is also recommended to start a groundwater level measurement program in different parts of the municipality to find out how the groundwater influences the level of I/I-water.

Every manhole is a puncture in the piping system. By including manholes in the wastewater system, we allow the I/I-water to enter the system at numerous weak points. The extent to which a full replacement of manholes alone, not in combination with the renovation of pipes, will reduce the level of I/I-water should be investigated. Whatever measure is chosen, the effect of the investments should always be evaluated.

Evaluating the impact of measures to control I/I-water is important but challenging. Because the volumes of I/I-water are so closely related to rainfall, it can be difficult to find two similar-and thus comparable - situations before and after the implementation of measures. Even if two or more rainfall periods have equally high volumes of rainfall, the ratio of rainfall to dry weather before those periods will affect the results. To get around this challenge, the proposed method of comparing results from a project area with a control area where no measures have been implemented may be appropriate. This was done successfully in this study. The method requires long series of data, which in and of itself can pose challenges.

Author Contributions: Conceptualization, K.J.S.; methodology, K.J.S.; investigation, K.J.S.; writingoriginal draft preparation, K.J.S.; writing-review and editing, J.T.B., O.G.L. and H.R.; supervision, J.T.B., O.G.L. and H.R.; project administration, K.J.S. All authors have read and agreed to the published version of the manuscript.

Funding: This research was funded by Asker Municipality and the Research Council of Norway. Grant number 272969.

Institutional Review Board Statement: Not applicable.

Informed Consent Statement: Not applicable.

Data Availability Statement: Not applicable.

Acknowledgments: The authors want to thank Asker Municipality for willingly sharing information and for giving access to data. The authors also want thank Asker Municipality and the Research Council of Norway for financing this study.

Conflicts of Interest: The authors declare no conflict of interest.

\section{References}

1. Rehan, R.; Unger, A.J.A.; Knight, M.A.; Haas, C.T. Financially sustainable management strategies for urban wastewater collection infrastructure-Implementation of a system dynamics model. Tunelling Undergr. Space Technol. 2014, 39, 102-115. [CrossRef]

2. Behesti, M.; Sægrov, S. Sustainability assessment in strategic management of wastewater transport system: A case study in Trondheim, Norway. Urban Water J. 2017, 15. [CrossRef]

3. Sola, K.J.; Kvaal, K.; Bjerkholt, J.T.; Lindholm, O.G.; Ratnaweera, H. Identifying factors influencing Infiltration and Inflow-water (I/I-water) in wastewater systems using multivariate data analysis. VANN 2019, 54, 263-278.

4. Karpf, C.; Krebs, P. Quantification of groundwater infiltration and surface water inflows in urban netwok based on a multiple model approach. Water Res. 2011, 45, 3129-3136. [CrossRef] [PubMed]

5. Franz, T. Spatial Classification Methods for Efficient Infiltration Measurements and Transfer of Measurings Results. Ph.D. Thesis, Institute for Urban Water Management, Dresden University of Technology, Dresden, Germany, 2007. 
6. Beheshti, M.; Sægrov, S.; Ugarelli, R. Infiltration/Inflow Assesment and Detection in Urban Sewer System. VANN 2015, 1, 24-34.

7. Zhang, M.; Liu, Y.; Cheng, X.; Zhu, D.Z.; Shi, H.; Yuan, Z. Quantifying rainfall-derived inflow and infiltration in sanitary sewer systems based on conductivity monitoring. J. Hydrol. 2018, 558, 174-183. [CrossRef]

8. Sola, K.J.; Bjerkoholt, J.T.; Lindholm, O.; Ratnaweera, H. Analysing consequences of infiltration and inflow water (I/I-water) using cost-benefit analyses. Water Sci. Technol. 2020, 82, 1312-1326. [CrossRef] [PubMed]

9. Assessing Infiltration and Exfiltration on the Performance of Urban Sewer Systems; European Commission: Lyon, France, 2005.

10. Guo, S.; Shi, X.; Luo, X.; Yang, H. RIver water intrusion as a source of inflow into the sanitary sewer system. Water Sci. Technol. 2020, 82. [CrossRef] [PubMed]

11. Sola, K.J.; Bjerkholt, J.T.; Lindholm, O.G.; Ratnaweera, H. Infiltration and Inflow (I/I) to Wastewater Systems in Norway, Sweden, Denmark, and Finland. Water 2018, 10, 1696. [CrossRef]

12. Lindholm, O.; Bjerkholt, J. Store fremmedvannsmengder i norske avløpsanlegg (Large Quantites of I/I- water in Norwegian wastewater systems). VANN 2011, 1, 5-14.

13. Ellis, B.; Bertrand-Krajewski, J.-L. Assessing Infiltration and Exfiltration on the Performance of Urban Sewer Systems; IWA Pulishing: London, UK, 2010.

14. Panasiuk, O.; Hedströn, A.; Langeveld, J.; de Haan, C.; Liefting, E.; Schilperoort, R.; Viklander, M. Using Distributed Teperature Sensing (DTS) for Locating and Characterising Infiltration and Infow info Foul Sewer befor, during and after Snowmelt Period. Water 2019, 11, 1529. [CrossRef]

15. Straufer, P.; Scheidegger, A.; Rieckermann, J. Assessing the performance of sewer rehabilitation on the reduction of infiltration and inflow. Water Res. 2012, 46, 5185-5196. [CrossRef]

16. Norsk Vann. Bedre VANN (The Norwegian Benchmarking System for Water and Wastewater Services). Available online: https:/ / bedrevann.no/pdf/bedreVANN2019.pdf (accessed on 15 October 2020).

17. Asker Kommune. Kommunedelplan Vann; Kommunalteknisk Avdeling: Asker, Norway, 2017.

18. Rosim AS. Precipitation in Asker Municipality. 2018. Available online: www.regnbyge.no (accessed on 28 September 2018).

19. Rosim AS. Målerapport. Målekvalitet -5 Vannføringsmålere (Regarding Quality of Measuring Points in Asker); Rosim AS: Oslo, Norway, 2020.

20. Nivus. Measure Analysis Optimise. Available online: https:/ / www.nivus.com/en/ (accessed on 17 June 2021).

21. Nivus. NIVUS-Instrumentering for Vannbransjen. Available online: https://www.nivus.com/en/nivus-international-entrypages/norway/ (accessed on 17 June 2021).

22. Rosim AS. About Rosim. Available online: http://web.rosim.no/ (accessed on 17 June 2021).

23. Asker Municipality. Water and Wastewater Regulations for Asker. Available online: https://www.va-norm.no/wp-content/ uploads/2015/12/Bilag-5-Gr\%C3\%B8ftesnitt.pdf (accessed on 17 June 2021). 